\title{
Haji Abdul Rahman Limbong (1868-1928) Fighter Against The Colonialist
}

\section{Berhanundin bin Abdullah}

Faculty of Islamic Contemporary Studies Sultan Zainal Abidin University; berhanudin@unisza.edu.my

Kamaruzaman bin Yusoff

Faculty of Islamic Civilization, University Technology of Malaysia (UTM), 81310 Johor Bahru, Malaysia; y.kamaruzamn@utm.my

\section{Mansoureh Ebrahimi}

Faculty of Islamic Civilization, University Technology of Malaysia (UTM), 81310 Johor Bahru, Malaysia (Corresponding author: Mansoureh Ebrahimi) E-mail: mansoureh@utm.my

\section{Ruzaini binti Sulaiman @ Abd Rahim}

Pusat Pendidikan Asas Dan Liberal Universiti Malaysia Terengganu; ruzaini@umt.edu.my

Doi:10.5901/mjss.2015.v6n6s1p281

\begin{abstract}
Haji Abdul Rahman Limbong was a religious scholar and a Malay fighter feared by the British colonialists. British had regarded him as a rebel. He was more known to many as a religious teacher, as well as a successful trader and entrepreneur. The present study investigates Haji Abdul Rahman Limbong's struggle with a focus on three objectives. Firstly, he defended the rights of the settlers and the people of Terengganu from further being governed by the British power. Secondly, he adopted the approach of religious studies to the people, title defence through the Court ruling, opposing to the colonial power through the spirit of Jihad and defending the politics of the state by means of the legislation. Thirdly, he ennobled the Sultanate institution and gave an undivided support to the state administration. A qualitative approach by analyzing available documentation from Public Record Office, Terengganu, is employed to reveal the aims of this study. It is highlighted that defending the people had been the central cause for Haji Abdul Rahman Limbong's struggle.
\end{abstract}

Keywords: Haji Abdul Rahman Limbong, Terengganu, Malay fighter

\section{Introduction}

Haji Abdul Rahman Bin Abdul Hamid Bin Abdul Kadir is better known as Haji Abdul Rahman Limbong, or in short, Tok Limbong. He was born in Kampung Jenguk Tong, Beladau Kolam, Kuala Terengganu. Some claimed that he was born in Belukar Bilang, Ulu Telemong, a village where his mother Tun Tijah came from (Timah bt. Hamzah 1981:27). He was known as someone with a courteous manner, friendly, a man whose good education and good upbringing are reflected upon him but only in few things that matter and true. He was depicted by George Alaxender de Chazen de Moubray as (PRO Co. 717/61/1, 1922, p. 1):

"a very holy man with a very big influence and very generous to the rakyat"

Haji Abdul Rahman has a small frame of a body, and his manner and appearance are similar to a sufi (Abdullah Zakaria bin Ghazali, 1985:60), he is dark-skinned and is of a Malay descendancy. He was born in 1868 (PRO Co. $717 / 61 / 1,1922$, p. 2). He is well-known, influential, has a good job, a religious scholar and surrounded by a society in the middle part of the Terengganu River. He was collectively acclaimed as a charitable man and known for his unselfish ways. He had chosen to be a teacher in the field of theology, agriculture (on 'Usyur: an agricultural method and starting a land the Islamic way) solat as an act of devotion. He had a lot of properties, as in Kemaman where the Chinese were allowed to develop the properties there. Other than that, he was also a silat teacher and was very good at handling and playing with weapons.

He obtained his education from his uncle, Haji Tun Mohammad Zain (Tun Mamat) in Mecca. His teacher was Haji 
Yaacob Paya Bunga having returned to Terengganu, for a period of two months and he had successfully mastered his education comprehensively. Then, he was under the supervision of Haji Wan Musa, in Paya Bunga also Tok Ku Paloh (Muhammad b. Abu Bakar, 1991:191).

The name "Limbong" was given to Haji Abdul Rahman because in a few years having been a religious teacher, he always travelled to and fro to Limbong which is located by the riverside in Bandar Cukai, Kemaman to teach, other than doing his business (PRO Co. 717/61/1, 1922, p. 3 - 4). Haji Abdul Rahman practised Tarikat Naqsyabandiah and upheld the figh of al-Syafie. This tarikat originated from Turkestan and founded by Muhammad Bahau'ddin Al-Uwaisi Al-Bukhari (1317-1389) (Abdullah bin Ali 1976:115). He was said to have saintly power, an extraordinary, miraculous power.

Haji Abdul Rahman was really careful about the halal or haram when it comes to the food he ate. He always distanced himself from being influenced by worldly materials. His home was equipped with everything in moderation. Meanwhile, his everyday clothes were the Malay attire or white robes, Chinese-cut pants, terendak and terompah. He also honoured people who had returned home from Mecca, with the title Haji to their names, and encouraged them to wear a white turban among them. Other than that, the hut students (basically students learning religion in schools in the forms of huts) had been appointed to serve as young leaders in the context of the rural Malay Community (Muhammad Abu Bakar 1991:214 and 215).

\section{Working Experiences}

Haji Abdul Rahman was a religious teacher. He was a really committed Muslim and performed the deeds collectively, then teached religion and solved a number of important issues in the community. When he was being made a political detainee in Mecca, he also taught in the Mecca Mosque (Timah bt. Hamzah 1981:118). His scholars were mostly the people of Malaya who came to learn in Mecca and then performed Hajj at the same time. His position and role as a teacher in Mecca had proven his credibility in the theological field, something that made him distinctive and special. He was also an entrepreneur, a hardworking and charitable trader and farmer. He did part of his daily routine as an entrepreneur, weaving fabrics to be made clothes, making terompah, terendak and agricultural tools and equipment. As a successful trader, Haji Abdul Rahman had sent 500 tonnes of chalk to Kuantan with his own big ship manhandled by five crew members and led by Haji Wan Nawang Sedara, without him being present (Timah Hamzah 1981:39). Haji Abdul Rahman Limbong had spread his business to countries abroad namely Menara, Southern Thai to sell his boat there (Abdullah Zakaria bin Ghazali 1985:73). As a farmer, together with the villagers, he resorted to planting cotton, banana, corn and paddy. As a charitable man, he loved to help the poor and fed the orphans and those in need especially during the Fasting Month (Timah Hamzah 1981:39). He held on to the principle that this earth belongs to God and anyone can seek for his or her own sustenance and form of livelihood and get His blessings, as long as their actions do not contradict the laws of Shari'a (Abdullah bin Ali 1976:115).

\section{The Fight To Defend the Fate of The People}

Haji Abdul Rahman struggled to defend the fate of his fellowmen by way of opposing to the British especially with regard to land development. At the end of the year 1921, the British had made effective several regulations on forest clearing control to enable the plantations of hill crops and other impermanent crops. Two of the related issues are the Land Office permit for temporary workers was with an annual pay of 50 cent per acre and that the issue of forests more than 7 years old cannot be felled (PRO Co. 717/61/1, 1922, p. 1).

Haji Abdul Rahman Limbong was against this authority and he had obtained the support from the village people in Hulu Terengganu. In July and August 1922, the people of Sungai Telemong came to gather in Telemong under the leadership of Mat Zain bin Mat Min, Haji Kia and Lebai Deraman (Tok Janggut). They worked on a land in Beladau as they normally would, without the permit and this was managed by Haji Abdul Rahman. The effort done by these locals had been regarded by the British as betraying them (Abdullah Zakaria bin Ghazali 1985:62).

\section{The British Threat on Haji Abdul Rahman}

The English administration felt that they were challenged by Haji Abdul Rahman's attitude and the villagers' discreet actions. They threatened to arrest and punish these locals. First of all, the government had issued a warrant on the 43 people who had cleared and opened land without any permit or pass. In the trial, if they were found guilty, they would be fined $\$ 100$. Haji Abdul Rahman made the effort to stand by the people when he asked for the Pleader License from the govenment, so that one can be a defender to the trialled community. He chose a legislative path to take a stand with the 
society (Abdullah Zakaria bin Ghazali 1985:62) with the aim to explain the accusation to the Malaya Commissioner (Tengku Bijaya).

A trial was held between Haji Abdul Rahman with an English attorney represented by the Forest Ranger. Haji Abdul Rahman had put forth a commentary that shocked the Forestry officer in Arabic handwriting (meaning land as being owned by the non-state administrator, and the state does not have the right in land rental). Judge Wan Mahmud had received the argument in response to the claim and the case was kept to serve as evidence (PRO Co. 717/61/1, 1922, p. 1). Haji Abdul Rahman had won in this first trial.

The Land Office had pledged with the High Court and the case was heard on 31st October 1922. A. Cheers, the Police Commissioner had come to the Court and it was found that in the room of the Court Judge, a Malay Judge had killed himself. A trial was also started between the Land Commissioner and Haji Abdul Rahman Limbong. The Land Commissioner asserted that he was given the mandate to control land distribution. Meanwhile, Haji Abdul Rahman questioned "What is the form of the government now? What are the form of the barren land and the requirements in the al-Quran?" The question was heavy and the trial was postponed on 6 November 1922 (Monday). He and his followers between 800 and 1,000 people had left the Court victoriously (PRO Co. 717/61/1, 1922, p. 1). The trial was postponed on the excuse that there were a lot of followers who came with weapons and were arrested. The British was angry thus the case was associated with the presence of too many followers (PRO Co. 717/61/1, 1922, p. 2).

$\mathrm{Mr}$ Cheers had sent a police constable to invite Haji Abdul Rahman to offer an explanation about the assembly and the land clearing that had taken place in Telemong. Haji Abdul Rahman had responded through Tengku Haji Abdullah saying that he did not want to come as his health was poorly. Again, A. Cheers had sent a messenger asking Haji Abdul Rahman to come to the Police Office on Thursday, 2 November 1922, and again he did not turn up since the Wednesday before that was a public holiday, in conjunction with Maulidur Rasul (PRO Co. 717/61/1, 1922, p. 3).

Secondly, using force. A. Cheers had gone to his home with a Sub-Inspector Syed Harun to bring him to the Police Station to make statement but it was declined. With that, A.Cheers had given a warning that Haji Abdul Rahman reconsider his invitation. If he still refused to do so, he would have to use force (Abdullah Zakaria 1985: 63). Cheers' next presence to detain Haji Abdul Rahman by sheer force had not been successful. This reluctance had ignited British's anger and potentially there would be an impending bloodshed.

The British Advisor then used his power and Dato' Seri Amar Diraja on behalf of the government through Sheikhul Islam (head of the Religious Department) to invite Haji Abdul Rahman. The British Advisor, J.L.Humphreys had made the decision to sue Haji Abdul Rahman Limbong through Sheikhul Islam on the pretext of inviting the society during the trial. J.L Humphreys had managed to persuade Syeikh al-Islam Tuan Embong (Sayyed Abu Bakar son of Tok Ku Paloh) to issue a warrant towards Haji Abdul Rahman. Wan Mahmud, the Judge of the Subordinate Court was asked to send the warrant to Haji Abdul Rahman.

Thirdly, file an accusation. At the Police Station, A. Cheers had read the accusation and statement that was taken through threat from those who came with weapons. Having been denied by Haji Abdul Rahman Limbong, A. Cheers had warned him to remind the rakyat not to be present and linger on the court's lawn during the trial. He continued to show his protest and disagreement with British's demands and was reluctant to go to the Police Station as he was discontented with A. Cheers' attitude. He denied being in a conspiracy causing Cheers to postpone his investigation until Appeal Land Office (PRO Co. 717/61/1, 1922, p. 7) had made the decision. In a few hours, Haji Abdul Rahman had come with Wan Mahmud to the Council room and followed by their followers who gathered outside the building. He sat next to Mr J.L. Humphreys. Mr J.L. Humphreys explained that the spectators coming to the Police Station and giving statement about the presence of the villagers, can be associated with a gathering aiming to show opposition against the government and were a form of betrayal towards the Sultan and the Malay race itself (PRO Co. 717/61/1, 1922, p. 6). Haji Abdul Rahman maintained that he did not ask the villagers to come to listen to the trial, and he was not involved in the 1922 assembly. With that, Dato' Seri Amar Diraja suggested that A. Cheers drop the charge on Haji Abdul Rahman.

Haji Abdul Rahman's use of his influence to prevent the public from coming to the Court during the trial had still failed. The British claimed that it was all an act. On 5 November 1922, J.L. Humphreys asked the Assistant of the Land Commissioner to handle the appeal cases but the trial was put on hold after 14 days without any action being taken.

Fourth, cancelling the attorney's license. J.L. Humphreys was clearly disappointed for the failed trial. To overcome this, J.L. Humphreys had conducted a discussion with Dato' Amar Tengku Bijaya (Land Commissioner), Syeikh al-Islam and the Mufti to cancel the Pleader License (Attorney) without compensation to the holder based on the Pleader License Enactment (PRO Co. 717/61/1, 1922, p. 8). Humphreys suggested that the government retract the attorney's license that was given to Haji Abdul Rahman and asserted that the government retract the license under the provision of law No. 2 of 1339 (199/20/1921). This law dictates that the govenment can cancel the license without compensation to its holder. This proposal was agreed by Dato' Seri Amar Diraja, Syeikh al-Islam and Engku Said (a relative to Tok Ku Paloh). 
The date of the trial was positponed to 20 November 1922. Haji Abdul Rahman had chosen the same date with this trial to hold a circumcision ceremony for new Muslims (Chinese origin) who embraced Islam in Terengganu with the idea that the trial was not going to be attended by his followers. In the ceremonial feast, a grand-scale procession was going to be held, with 1000 Malays attending, 4 cows and 400 chickens slaughtered (PRO Co. 717/61/1, 1922, p. 8). The ceremony was postponed due to the threat and coaxing of the Court, asking for the ceremony to be cancelled.

Fifth, cancelling the certification of the government representatives and religious teachers. On 19 November 1922, Syeikh al-Islam had sued Haji Abdul Rahman and asked him to come to the Religious Office. He did turn up on the date scheduled. Also present at the office were Sheikh al-Islam, Mufti, Dato'Seri Amar Diraja, Tengku Bijaya (Land Commissioner) and J.L.Humphreys. In this meeting, Haji Abdul Rahman was told that the government's duty was to uphold peace and the duties he had to carry out as a representative were marred, especially when he was characteristically a pious man. Haji Abdul Rahman was advised to take part in good activities and not to get personally involved in any movements at all. His duty as a representative of the government and the mosque's religious teacher was cancelled. His license was also retracted and he was not permitted to hold any circumcision ceremony (PRO Co. 717/61/1, 1922, p. 9). Haji Abdul Rahman Limbong did not go against this cancellation, but instead maintained that his engagement in the trial was to assure that the rakyat were treated with justice. He also explained that there were oppression and extortion committed by the Land Officer. In this matter, Haji Abdul Rahman Limbong was given the assurance that the government would report any single misappropriation committed by its officers and it would be more careful in taking any actions. However, the trial that was postponed was no longer continued after that date.

On the 20 November further postponement was done by the Land Office. J.L. Humphreys simply could not bear reporting this. He arranged for a team from the Court of Appeal comprising of himself, Mufti and Syeikh al-Islam to Pulau Babi (10 km from the Terengganu River) visiting a piece of land. His sole purpose was to obtain evidence of Haji Abdul Rahman's influence. They arrived at Pasir Tembakang (6 km from Town) and encountered hundreds of Malay gathering on a spacious area, with boats full of people who came from different directions, with some huts built, cows slaughtered, food cooked, and prayers read as full preparation for the Chinese Muslims's circumcision religious ceremony. On their way back, the ceremony had ended and the boats were nowhere to be seen. This had left a great impact to the British (PRO Co. 717/61/1, 1922, p. 9).

J.L. Humphreys reported that the most dangerous disruption had come to an end. It might be the effect of the infamous Kelantan rebellion in 1915. The nobility and credibility of Haji Abdul Rahman had elevated him to a position of a powerful, dangerous leader although he had a village background like Tok Janggut, with his high spirit of fighting for religious causes (PRO Co. 717/61/1, 1922, p. 9).

Haji Abdul Rahman had encouraged the people of Telemong and claimed that they had been owning the land there since generations ago, and he continued to oppose the government people, who attempted to guard along the river. J.L. Humphreys in his report, stated that the rebellion that took place in Kelantan had seemingly served as the basis of the protest. Anti-foreigners demonstrations were the result of the failing British land administration (PRO Co. 717/61/1, 1922, p. 10).

Sixth, acting through the 'rule and divide' approach. Having lost a few times in the trials on land issues, some subtle actions through the 'rule and divide' approach had to be carried out. J.L. Humphreys had instructed the Police Commissioner to do another hearing on the case of a man bringing weapons into town on the 31 October. The process would weaken the influence of Haji Abdul Rahman, whether it rejected or supported him J.L.Humphreys hoped that there was a sense of weakness in Haji Abdul Rahman that could be diverted using some administrative influence and for it to stimulate the farmers to work well, with the allocated roads underway (PRO Co. 717/61/1, 1922, p. 10). The people were encouraged to get involved in the land clearing to build more roads. This was to win the attention of the people and to make them afraid of the government's actions (Muhammad Abu Bakar 1991: 198-199).

\section{Haji Abdul Rahman's Successful Opposition Against the British}

In the year 1923, Haji Abdul Rahman representing a number of people from Hulu Terengganu, especially the area of Telemong, had helped them forward a letter to the Terengganu Land Commissioner (SUK. Tr. 599/1342, 1924). His aim was to ask him to consider the issue of land ownership equality right and the pass obtainment process. He hoped that these issues would be brought forth to the government. The solution should also take into account the rakyat's affordability.

Haji Abdul Rahman told the Land Commissioner that he represented the 508 members of the community who had cleared the land without a pass, had mortgaged some money amounted to 250 ringgit as evidence that they did not violate the government's order (Muhammad Abu Bakar 1991:199). It also served as an assurance and mandate that the 
government could not sue, arrest, fine or imprison them. He maintained that the land was their own and not governmentowned.

Evidence of ownership is based on the fact that the residents of the District of Hulu Sungai Terengganu, Telemong, Berang, Tersat also Hulu Nerus were the native residents of Terengganu. Although there were some of them originated from Johore, this generation had come with Sultan Zainal Abidin I during the formation of the Terengganu administration in Tanjung Baru then. The bushes and small forests were due to the fact that the farmers had worked on their lands in turn. From the time of Sultan Zainal Abidin I (1725-1733) right to that of Sultan Zainal Abidin III (1881-1919), there was no disturbance of ownership on the land of plantation, and even Sultan Zainal Abidin III had granted ownership without charging any fees at all.

Meanwhile, Haji Abdul Rahman's suggestion that no investigation should be done on the land, was not agreed by the British Advisor and Dato'Seri Amar Diraja. In his memorandum to Dato'Seri Amar Diraja on the 3 February 1924 (26 Jamadil Akhir 1342), the British Advisor had suggested that the money sent by Haji Abdul Rahman was made the fee revenue tax. This suggestion was agreed by Dato' Seri Amar Diraja (SUK. Tr. 599/1342, 1924).

Haji Abdul Rahman had also disagreed with laws involving wild animal control as the people were restrained from shooting wild boars which had threatened them when they worked. Those who violated would be fined. In 1923, laws on restrictions and prohibitions for pets and livestocks were renewed. The police, home and plantation owners were allowed to catch animals that roamed free, destroyed properties and crops and brought to the slaughter house. The animals would be caged until their owners came and paid for the fine of $\$ 10$ together with a compensation fee of $\$ 10$.

In February 1924, the Government Meeting Council had passed a land settlement law enactment where the law was unanimously agreed to have been a burden to the rakyat (Timah Hamzah 1981:70). The residents of Telemong again, rose to the occassion, in their opposition against the gazetting of the 1924 Land Settlement Enacment. They continued working without caring for the said enactment. 43 people were fined and brought to the Subordinate Courts on the charge of opening the land without permission. Haji Abdul Rahman Limbong had taken extra measures to defend those who were penalised.

On the 28 Disember 1924, the regulation for the Animal Control Law was again amended and only imposed on the cows. Cows were not allowed to roam free on the roads, except if they had the nose rope and could be pulled by their owners. If the cows were caught, and in the period of seven days, they were not claimed, then the cows would be auctioned. For fierce cows, they would be slaughtered to ensure the safety of the people.

The success of Haji Abdul Rahman had raised the awareness among the British that this man had the capability to launch an opposition towards the government. His credibility and strong religious influence had overcome and overpowered government's actions (Timah Hamzah 1980:64). Several cases have served as proof that he did not disobey the government, but he would accept it under the circumstances that the government's actions were appropriate and necessary (Timah Hamzah 1980:70).

Most of the Telemong residents had listened to the advice and views raised by Haji Abdul Rahman. If the government were to take action on those who cleared the land without a pass, those involved will go and complain to Haji Abdul Rahman at his home in Beladau (SUK. Tr. 1268/1342, 1924). There were also farmers who did not pay for themselves at the Land Office to get a pass, but instead had given the money to Haji Abdul Rahman for payment.

Haji Abdul Rahman had instructed Tun Uthman, Tun Umar, Wan Mat Amin, Wan Long and Tuan Mat Saleh to clear the land at the Bukit Pia orchard to grow cotton, banana and paddy. He was asked to go to the office in Kuala Berang but refused, for he had already informed this to the Terengganu Land Commissioner, but up until then he was yet to get a reply. He anticipated that if the land was imposed with tax, then he must be informed so that the tax can be settled and for the Telemong residents to not be burdened by this.

On the 12 June 1924, the British was not happy with the religious teachings delivered by Haji Abdul Rahman (SUK. Tr. 1268/1342, 1924) including the religious activities that he led. Due to this, the State Meeting Council had held a conference on 21 July 1924 (Saturday) and made the decision that all religious activities must be approved and those who violated this regulation, would be arrested. The arrest would not be exempted on Haji Abdul Rahman (SUK. Tr. 1268/1342, 1924). The rakyat did not protest this regulation, but they only held a feast instead. However, the British had regarded this as a form of protestation as they were informed that a major gathering was about to take place (SUK. Tr. 1269/1342, 1924).

\section{The Accusation on Haji Abdul Rahman}

The new British Advisor, J.W. Simmons had accused the Religious Department of being impatient to appoint Haji Abdul Rahman as a religious teacher in the local mosques with appropriate salary provided for him. He was also accused for 
not wanting to work, not being frank when refusing the offer and that he only taught in his pastime. The level of anger of this British Advisor was very high so much so that he stated that the affairs of Telemong were not something that needed to be discussed only because the affairs were all related to Haji Abdul Rahman (PRO Co. 717/61/1, 1925).

Regarding the opposition towards the British administration, M. L. Wynne (Pesurthe Police Commissioner) had just received news which validity was uncertain. He thought that 2,000 people had been under the command of "krah". Wok's clerk was said to not have any detailed information (name and village's name) from the 2,000 people who had given the feedback. The rumour from the Captain had it that they were ready to "instruct" people all over the state, from Kelantan to Kemaman and took some defensive steps as they were confident that they could dominate the entire state, wave off British influence, return the Sultanate to Sultan Muhammad (the brother of Tengku Nik) and appoint Haji Abdul Rahman as the Prime Minister. Wynne could not make sure of it but clearly Haji Abdul Rahman received support from Sultan Muhammad and the public, while Tengku Nik had been a traitor. Wynne explained that Haji Abdul Rahman was a very successful rebel, not an administrator and not a religious member as he had infused politics in his lectures and talks. He worked on leading the organisation (party) to be free from the grip of the foreign power that was finally retracted by the British Advisor (PRO Co. 717/61/1, 1925, p. 3 - 4).

In a letter dated 21 April 1925, signed by Haji Abdul Rahman it stated that Tengku Nik from Kampung Sungai Ular had sent a letter to the Chief Mahmud bin Mohamed Malim to clear a land in Kampung Lubuk Merbau and he came with a bushel of rice (PRO Co. 717/61/1, 1925, p. 3 - 4). Chief Abdullah had reported that on 2 May 1925 (Saturday) people who were in Ulu Malaya started to come to Mat Zin Bin Mat Min's land (Kuala Telemong) then they built five huts on the land. They were paid by Haji Abdul Rahman to clear the land of Tengku Nik Maimunah. They kept vigil in turn to prevent the land from being trespassed (PRO Co. 717/61/1, 1925, p. 1).

On the 3 May 1925, J.W. Simmons had reported that hundreds of Malay had arrived from the rivers of Belimbing, Tersat, Berang and Nerus (estimation was 300 to 500 people) to gather in Kuala Telemong several hours on the river of Terengganu. They wanted to clear the land of Tengku Nik Maimunah. This information was obtained from a letter that was distributed to the locals which contained three characteristics- (PRO Co. 717/61/1, 1925, p. 2), that the land was owned by Tengku Nik Maimunah (a gift for the Sultan's sister), that the name of Haji Abdul Rahman Limbong was noted and that the letter was written by Mat Zain's clerk named Wok.

M. L. Wynne, the Police Commissioner had reported that people involved in illegal assemblies had decreased, from 300 people to 100 people. Mat Zin bin Mat Min was the leader who had organized these meetings, while Haji Abdul Rahman was reported to be the mastermind of the gatherings (PRO Co. 717/61/1, 1925, p. 2). Chief Abdullah reported that he had never seen a 300-strong crowd in a single occassion. On 6 Mei 1925 there were about 50 men who were working that night (PRO Co. 717/61/1, 1925, p. 2).

J. L. Humphreys had included a copy of the "B" report from the Police Commissioner dated 6 May 1925 instructing the public to avoid from spreading anything uncertain in regard of any inaccurate statement issued by a Malay that can create any difficult issues, based on these reasons (SUK. Tr. 1269/1342, 1925):

1. Tengku Nik (the sister of the Sultan and the beloved daughter of al-Marhum Sultan Zainal Abidin) was a very influential member of the royalty and did not speak much.

2. Haji Abdul Rahman did not sign any letters and this would separate him from the issues.

3. It was difficult to get any clear case in relation to Haji Abdul Rahman although some claimed that he was the prime mover behind the movement that he himself did not join. The local people at the time had disputed the position of the British when it comes to colonization.

4. It was impossible for an European to meet and talk with him. Mr Wynne who was his neighbourfor two years stated that he did not know anything about him. The term "Kafir" was a fanatical term to use in the stream of thoughts bordered by religious belief.

Haji Abdul Rahman was accused to have been engaged in, and charged for gathering his village men by means of distributing invitation letters (SUK. Tr. 1269/1342, 1925). Following the assembly, a meeting was arranged between Tengku Bijaya (Head of the Religious Department) and Tengku Setia, the State Secretary with Haji Abdul Rahman at his home as to get statements about the event. He denied all the allegations and maintained that he was not in any way connected in the assembly and claimed that his name was manipulated without his consent and knowledge. His statements did not convince the British Advisor so again, Tengku Bijaya was instructed to visit Haji Abdul Rahman Limbong at his home to get some explanation and still, he gave the same answer. The British Advisor stated that Tengku Bijaya was inefficacious and was a little slow in handling matters. Then, he arranged that Tengku Bijaya and Tengku Setia, the State Secretary to see the Sultan to invite Tengku Nik and asked her to not "command" any more people to do land clearing job. He was informed that on the 8 May the Sultan had acted the way he was proposed to do so. Simmons instructed Tengku Bijaya to meet with Haji Abdul Rahman and discuss the purpose of the government who was 
seemingly embroiled in a minsunderstanding with the residents of Hulu Telemong. Tengku Bijaya took the responsibility with Mufti and Wan Sulaiman (Syeikh al-Islam Assistant) talking to Haji Abdul Rahman about the issue (PRO Co. 717/61/1, 1925, p. 3 - 4).

On 27 May, Dato' Seri Amar Diraja, Tengku Bijaya and Dato' Lela had gone to see Haji Abdul Rahman at his place carrying the mandate of Sultan Sulaiman Badrul Alam Syah, asking him to see the Sultan in Istana Kolam to give a statement on the assembly. Haji Abdul Rahman asserted that he did not have anything to do with, and even added that the administration of the Kuala Berang District Officer was oppressing the rakyat. In his meeting, Dato' Sri Amar Diraja asked Haji Abdul Rahman to lodge a report to the government if the rakyat were not satisfied and had come up with certain demands. The British advisor was not happy with the report and result of the conversation due to other arising problems in Hulu Terengganu (PRO Co. 717/61/1, 1925, p. 4).

\section{The British Oppression on Haji Abdul Rahman}

Several processes and implementation in Islamic religious welfare were intervened by the British officers, among which, in 1927, The British advisor had sent a letter to the Religious Commissioner to revoke the license of the Attorney En. Da bin Mohamad who was representing Haji Abdul Rahman under the charges of his misdemeanour and deceit. This proposal had led to the result of the licence revoked, as decided by the verdict of the general meeting and the State Government meeting (SUK. Tr. 1269/1342).

In March 1928, the government had issued a demand on the land yield, which ownership was determined. However, there were some of the residents who were not bothered by the demand as they were not granted ownership of the lands. Due to this, this issue was brought to the Magistrate Court. In the trial that had taken place, Haji Abdul Rahman was made the guilty party for his instructions, asking the people of Hulu to clear the lands and grow plantations. Having been sentenced, Haji Abdul Rahman Limbong had paid all fines imposed by the Court dated April 1928 on 30 people guilty of clearing the lands without legal pass (Terengganu 1928:21). This payment had rescued the local society from being imprisoned in Kuala Terengganu (Abdullah Zakaria 1985:72).

Following the incident, Haji Abdul Rahman was slandered, to have been spreading the idea opposing to the new regulations between 19 and 20 April 1928 in Dungun. On the 4 May 1928, Hulu Terengganu leaders such as Village Chief Salleh Pasir Nyior, Tersat, Tahir Pasir Padang, Abu Bakar Chinting, Mat Tuk Pitas, Encik Deraman bin Haji Daud, Peris, Abdullah Jurukaka and Ismail Kuala Por had gone to see Haji Abdul Rahman Limbong and Sayed Saggof to get some advice from these religious scholars. They were brought by Che Leh (Haji Abdul Rahman's son). In this meeting, Haji Abdul Rahman Limbong gave assurance that we would help the residents of Hulu Terengganu on the premise that they were brothers in Islam. The leaders were advised to not use and manipulate Haji Abdul Rahman's name arbitrarily. After being advised, the Hulu leaders returned to their daily tasks Berang, Sungai Besar, Telemong, Dungun and Marang. The meeting had become a basis for the accusation imposed on Haji Abdul Rahman under the pretext that he had slandered the local people to work on the land planting paddy or huma without having to take the pass and to gather in Kuala Berang.

The British continued to blame Haji Abdul Rahman, anytime something happened to the people at large. They referred to the report by J. L. Humphreys, the then-British Advisor in the case of opposition taking place in 1922 and the report written by Mr. J. W. Simmons (British Advisor from April 1925 to October 1927) in relation to the 1925 riot. The British accused Haji Abdul Rahman as the reason behind the riot incident in regard of the land tax, claiming that he influenced the local people to hate and rebel against the British and had been biased when it comes to religion-oriented issues. However, he stated that he and his followers had some interests in the establishment of "Parti Astana" and assumed that it was far from perfect (PRO Co. 717/61/1, 1928, p. 3).

The people's concern came to an end when they finally had the opportunity to meet Sultan Sulaiman when the Sultan left for Kuala Berang on 7 May 1928. It was estimated that between 2500 and 3000 residents came to file complaints and made appeals. Among them, included were six requests to be considered and approved from using a pass or license (Rahmat Saripan 1987:89) to take the leaves to make lemang and ketupat; wood to make houses and boats; pandanus leaves to make mats and awnings; to fell sago trees; to apply for markings between government-owned lands and resident-owned lands; to apply to use weapons to eradicate pests; to release the cows and to use the cows to pull timber.

Sultan had succumbed to all these pleas and made reference to the verdict issued by Sultan Zainal Abidin III in the issues concerning land development, the fact that the rakyat were free to open new lands and own them, they were free to fell the tress and clear the forests and take the wood and leaves for their rooftops (PRO Co. 273/351).

According to Rahmat Saripan (1987:92) the greatest opposition that happened in Terengganu was on 22 May 
1928 under the leadership of $\mathrm{Hj}$. Abdul Rahman Limbong aided by local leaders such as Che Ismail Kuala Poh, Engku Mat Kuala Pueh, Abdullah Juru Kaka, Mat Zin Mat Min Haji Kia (Zakaria), Jusoh Hitam, Village Chief Salleh Pasir Nyiour, Lebai Hassan, lebai Deraman located in Kuala Telemong. They were supported by 300 to 500 residents of Kuala Berang. This struggle was the struggle of the people to demand for the land development and undertaking rights. This opposition was rooted from the abundant rules on the people including including pet control rules, compulsory pass when working on huma, felling trees, taking the sago palm leaves, palm to make attap, taking sago, coconut leaves and salak. Even the Government Penghulu, Mat Ariffin would not permit anyone taking the woods, rattan and palm leaves (to make ketupat). Those who disobey would be reported to the police. (Abdullah Zakaria Ghazali 1984:285).

The pressure exerted by the British had created some tension in Hulu Terengganu and it has come to be known by Sultan Sulaiman. Unfortunately, the Sultan as willed by the British had instructed a 25-member team of police and an inspector to go there after they heard the news that 500 residents were moving to Kuala Telemong to merge with another team at Haji Mat Zin Kampung Pelam's residence, so the police team had returned to Kuala Telemong.

On 23 May 1928 a team of police had set camp behind the paddy fields in Padang Kachong. The police had opened fire at $11.30 \mathrm{am}$, costing the lives of 12 residents. Their leaders were arrested and put on trial on 11 June 1928 in Istana Maziah. Among the punishments imposed were (Abdullah Zakaria Ghazali 1976:13-21) Muhammad Zain bin Muhammad Amir (15 years of imprisonment, hard labour), Ismail bin Saleh (10-year imprisonment, hard labour), Abu Bakar bin Abdul Rahman (10-year imprisonment, hard labour), Abdullah Jurukaka (10-year imprisonment, hard labour), Haji Zakaria bin Mat Hassan (7-year imprisonment, hard labour), Chief Omar (6 year imprisonment, hard labour), Engku Mat Pueh (5-year imprisonment, hard labour), and Haji Tahir Gunung (5-year imprisonment, hard labour), Muhammad Pitas (5-year imprisonment, hard labour), Lebai Hassan (5-year imprisonment, hard labour), Chief Salleh bin Yusof and Saleh Haji Abdul Rahman released without sentence, Haji Abdul Rahman Limbong was made exile to Mecca with life sustenance of $\$ 30.00$ per month.

\section{Arrests and Punishment On Haji Abdul Rahman}

Haji Abdul Rahman Limbong was arrested in his home in Beladau as he was accused of being involved in a defence movement in 1928. He was brought to Istana Maziah to be interrogated on 28 May 1928 (7.12.1346) and also present were Dato' Sri Amar Diraja, British Advisor and the State Government Sceretary. The trial had taken place for about two hours from 3.00 to 5.00 in the afternoon. In his statement, Haji Abdul Rahman Limbong stated that he had only just returned from Menara, Southern Thai to sell his boat there. He strictly maintained that he had nothing to do with the assembly and he did not even know anything at all. He did not try to stop, nor disallow the surrounding community to take the pass (Abdullah Zakaria 1985:73). Then, Haji Abdul Rahman was arrested in a house in the vicinity of Istana Maziah as the authority was overly concerned that there would be chaos. This trial had been one of the political detainee trials as not even one offence could be imposed on the offender, Haji Abdul Rahman.

Based on the good advice from Dato' Sri Amar Diraja, Haji Abdul Rahman Limbong was sent into exile in Mecca. On the 2 June 1928 (12.12.1346) the State Government of Terengganu had declared that Haji Abdul Rahman Limbong was sent to Mecca. All his affairs to Mecca, including travelling expenses and self-sustenance were provided for by the State government. The State Meeting Board who had a conference dated 17 July 1928 (Isnin) had agreed to pay for his sustenance of 30 ringgit per month to Haji Abdul Rahman Limbong as long as his period of stay in Mecca or Madinah.

A record of conversation between Haji Abdul Rahman and Mr. J. D. Hall, the High Commissioner Secretary managed to be recorded on June 1928 during his transit from Terengganu to Mecca. Haji Abdul Rahman did mention that the people's opposition actually aimed to free the state from foreign influence and for them to freely spread and understand the Islamic teachings in the society. The society has risen to defend their rights that have been treated rather rudely by the British, especially as far as the poor in remote areas are concerned. Undivided support had been given to ulama or religious scholars who were willing to join them defending the fate of the Malay race (PRO Co. 273/351).

After being in exile for several months in Mecca, on the 22 October 1928 Haji Abdul Rahman Limbong had sent a letter to Sultan Sulaiman Badrul Alam Shah as a pledge to allow him to return home. Some discussions had later ensued, following this. The decision that had been made unanimously in the State Meeting Council dictated that Haji Abdul Rahman's plea was declined, on the grounds that his influence would ignite more chaos in Hulu Terengganu. As he was not permitted to return to his hometown, he continued to teach theology and religious knowledge to the Malays who came to Mecca.

On 13 November 1928 Haji Abdul Rahman Limbong had written an Authoritative Letter to Haji Wan Embong bin Haji Muhammad in Kota Lama to administer properties, payments and debt collection and provide sufficient life sustenance to his wife. Haji Wan Embong was given the authority to sell the properties if it was deemed necessary. Haji 
Abdul Rahman Limbong anticipated that all his debt payments must be borne witness by the judge (Abdullah Zakaria, 1985:75). On 6 November 1929 or 14 Jamadil Akhir 1348, Haji Abdul Rahman Limbong passed away in the home of Haji Muhammad (Haji Muhammad Waqaf Home) that was already prepared for him to stay. He passed away in his sickness and was buried in a cemetery in Mecca (Timah bt. Hamzah, 1981:119).

\section{Conclusion}

Haji Abdul Rahman Limbong's noble character has evidently demonstrated that truth is in favour of the people. He was slandered and alleged on many accounts despite him not attending many community-based activities. His sacrifice was idolised by the people, for he was seen not only as an 'ulama' or a pious scholar, but also as a middleman who was bold enough to defend the fate of his own countrymen. He resolved any issue in regard of the people undisputedly. All convictions that had been imposed upon Haji Abdul Rahman Limbong were a series of strategies of the British, to the point that he was successfully made an exile. After the passing of Haji Abdul Rahman Limbong, it marked the end of the British's relentless efforts to combat the pious group to the very end, because to these colonialists, Haji Abdul Rahman Limbong was the last scholar who was willing to fight against the British Supremacy.

\section{References}

Abdul Aziz Ismail. 1996. Suka Duka Kepimpinan Ulama dan Penguasa: Mendaulatkan Hukum-hukum Allah dan Menangani Permasalahan Ummah. Johor Baharu: Jahabersa Trading.

Abdullah bin Ali. 1976. "Peranan dan Pengaruh Ulama Said Abdul Rahman b. Muhammad Al-Idrus dalam sejarah kemasyarakatan Negeri Terengganu.Pertengahan abad ke 19 hingga ke year 1920-an". Academic training for Bachelor Degree in Arts (1975/1976). Kuala Lumpur: History Department, National University of Malaysia.

Abdullah Zakaria Ghazali. 1976. "Haji Abdul Rahman bin Abdul Hamid", in Malaysia In History. Vol. 1. Kuala Lumpur: Malaysian History Association.

Abdullah Zakaria Ghazali 1984. Bantahan dan rundingan: Campurtangan British dalam pentadbiran Terengganu, 1909-1919, in Terengganu: tokoh, pentadbiran dan perjuangan, Museum Association Malaysia, Kuala Lumpur.

Abdullah Zakaria bin Ghazali. 1985. "Kebangkitan Anti British di Semenanjung Tanah Melayu". Editor Khoo Kay Kim. In Sejarah Masyarakat melayu Moden. Kuala Lumpur: Publication Dept, Universiti Malaya.

Mohammad Endut, 1970. 1928-Penderhakaan Di Terengganu. Academic training for Bachelor Degree in Arts. Kuala Lumpur: History Department, Universiti Malaya.

Mohd Isa Othman 1992. Pendudukan Jepun di Tanah Melayu. Kuala Lumpur: Dewan Bahasa dan Pustaka.

Muhammad b. Abu Bakar, 1991. Ulama Terengganu Suatu Sorotan. Kuala Lumpur: Utusan Publication and Distributors Sdn. Bhd.

Public Record Office, Terengganu: Co. 717/61/1, Enclosure No. 4. Report On Certain Matters Connected With One Haji Drahman of Terengganu, by. J.L. Humphreys 24th November 1922.

Public Record Office, Terengganu: Co. 717/61/1, Enclosure No. 5. Report On Certain Matters Connected With One Haji Drahman of Terengganu, by J.W. Simmons $10^{\text {th }}$ July 1925 .

Public Record Office, Terengganu: Co. 717/61/1, Enclosure No. 5. Report On Certain Matters Connected With One Haji Drahman of Terengganu, NO. 2. in C.P.Tr. 57/25: Office of the Commissioner of Police (Unlawful Assembly At Kuala Telemong) 6 $6^{\text {th }}$ May 1925.

Public Record Office, Terengganu: Co. 717/61/1, Enclosure No. 5. Report On Certain Matters Connected With One Haji Drahman of Terengganu, NO. 2. in C.P.Tr. 57/25: Office of the Commissioner of Police (Unlawful Assembly At Kuala Telemong) $6^{\text {th }}$ may 1925. (Statement of Penghulu Abdullah of Kampung Kuala Telemong)

Public Record Office, Terengganu: Co. 717/61/1, Enclosure No. 5. Report On Certain Matters Connected With One Haji Drahman of Terengganu, NO. 2. in C.P.Tr. 57/25: Office of the Commissioner of Police (Unlawful Assembly At Kuala Telemong) 6 ${ }^{\text {th }}$ may 1925. (Report by Dato' Menteri).

Public Record Office, Terengganu: Co. 717/61/1, Enclosure No. 6. Unfederated Malay States (Terengganu). 6 th December 1928.

Public Record Office, Terengganu: Co. 717/61/1, Unfederated Malay States (Terengganu), Colonial Office, by High Commissioner For The Malay State. $6^{\text {th }}$ December 1928.

Rahmat Saripan 1987. "Pemerintahan di Kelantan dan Hubungan Dengan Patani dan Terenggannu dalam Abad ke 18", Kelantan Zaman Awal: Kajian Arkeologi dan Sejarah Di Malaysia. Kelantan: Kelantan State Museum Corporation.

Terengganu. SUK. Tr. 599/1342. The Deputy of the Menteri Besar to British Advisor, 26.6.1342, (3 February 1924).

Terengganu. SUK.Tr., 1268/1342. Kuala Berang Commissioner to the Secretary of the Terengganu State Government, 11 June 1924.

Terengganu, SUK.Tr., 1269/1342. Government Medical Office (Hospitals) to the Secretary of the Terengganu State Government, 12 June 1924.

Terengganu, SUK. Tr 369/1346. State Government Secretary

Terengganu, SUK Tr. 145/1347, 406/1347, 635/1347. Terengganu Government Report.

Timah bt. Hamzah 1980. Pemberontakan Tani 1928 Di Terengganu. History Bachelor's Degree Thesis, Faculty of Social Science and Humanity. Bangi: National University of Malaysia

Timah bt. Hamzah 1981. Pemberontakan Tani 1928 Di Terengganu. Kuala Lumpur: Dewan Bahasa dan Pustaka. 